\title{
THE EFFECT OF HEMICASTRATION ON DAILY SPERM OUTPUT IN THE RAT AS MEASURED BY A NEW METHOD
}

\author{
J. T. M. VREEBURG, M. V. van ANDEL, W. J. KORT* AND \\ D. L. WESTBROEK*
}

Department of Endocrinology, Growth and Reproduction, and

*Laboratory of Experimental Surgery, Medical Faculty, Erasmus University, Rotterdam, The Netherlands

\section{(Received 14th February 1974)}

\begin{abstract}
Summary. A method for anastomosing the ductus deferens end to side with the bladder in the adult male rat is described. In such rats, the sperm output was measured 1 day each week for more than 4 months by counting the number of spermatozoa in the 24-hr urine. Immediately after hemicastration, the sperm output diminished to half the preoperative level and remained at this level during the next 3 months.
\end{abstract}

\section{INTRODUCTION}

When repetitive determinations of sperm production are required, as when studying time trends, or testing treatment effects on the same individual, counting spermatozoa in ejaculated semen is considered to be the method of choice (Amann, 1970a). The procedure for measuring the daily sperm output is to obtain ejaculates from the animals at short and regular intervals after a series of preliminary sperm collections have been performed to exhaust the epididymal sperm reserve. Methods of collecting spermatozoa from rats by electrical stimulation of the anus have been reported (Scott \& Dziuk, 1959; Birnbaum \& Hall, 1961; Lawson, Krise \& Sorensen, 1967). Counting the number of spermatozoa in the ejaculate of the rat can be carried out after liquefaction of the copulatory plug, which contains a considerable number of spermatozoa (Mauss, Rausch-Stroomann, Hahn, Petry \& Zambal, 1970), but the reliability of this method for the rat is difficult to assess because it is known that these animals spontaneously emit spermatozoa (Orbach, 1961). We have recently sought an alternative to the traditional method for vasectomy and examined the possibility of connecting the ductus deferens with the bladder. In this way, we hoped to prevent the formation of cysts in the epididymis and the ductus deferens (Smith, 1962; Sackler, Weltman, Pandhi \& Schwartz, 1973) and the formation of antibodies against spermatozoa, both of which often occur in the rat after vasectomy or vasoligation (Rümke \& Titus, 1970). After it was found that the operation could be carried out easily and that many

Correspondence: Dr J. T. M. Vreeburg, Department of Endocrinology, Erasmus University, P.O. Box 1738, Rotterdam, The Netherlands. 
spermatozoa were present in the urine, we investigated the possibility of measuring the daily sperm output by counting the spermatozoa in 24-hr urine samples. The effect of hemicastration on the sperm output in the rat was also studied.

\section{MATERIALS AND METHODS}

Ten male hooded rats born in the Erasmus University breeding unit and housed under controlled temperature and lighting conditions (14 hr light/24 hr) were used for this study. At the beginning of the experiment, the animals were about 100 days of age.

During the 3 weeks before the first operation, each rat was placed once a week in a metabolism cage for $24 \mathrm{hr}$ to measure the number of spermatozoa passed in the urine of the intact animals. The sperm concentration was determined with a haemocytometer. The daily sperm output was calculated from the sperm concentration and the urine volume. Anastomosis between the ductus deferens and the bladder was then achieved. The rats were anaesthetized with ether and a 4-cm mid-line abdominal incision was made from the xiphoid to the penis. The abdomen was opened and the bladder and ductus were cut approximately $1 \mathrm{~cm}$ from the urethra, taking care not to harm the vessels. Two small lateral incisions were made into the bladder and, using a needle and an atraumatic $7 / 0$ silk suture, each testicular segment of the ductus deferens was pulled into the bladder and sewn to its inside wall (Text-fig. 1). The incisions of the bladder were closed with the same silk sutures and the muscles and skin of the abdominal wall were closed with catgut and wound clips, respectively. Sperm output was successfully measured in nine of the ten rats during the following 6 weeks. Four of these males were hemicastrated abdominally 7 weeks after

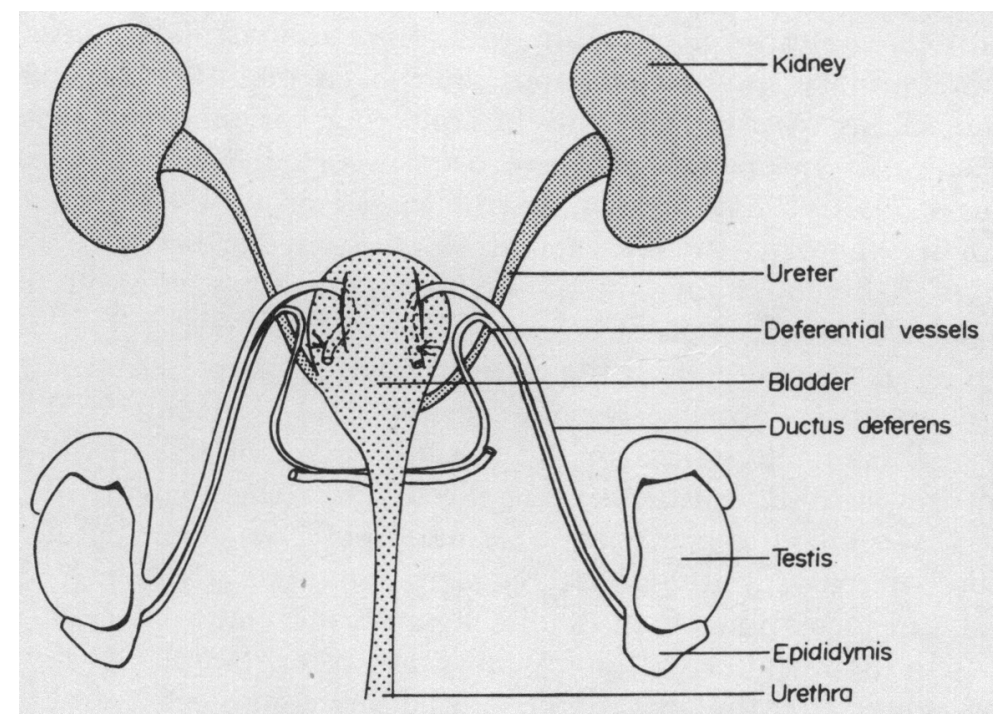

TEXT-FIG. 1. Diagrammatic representation of the anastomosis between the ductus deferens and the bladder in a rat. 
initial surgery (Group 1) and the remaining five were subjected to sham operation as controls (Group 2) by opening the abdomen, exposing one of the testes, returning it into its scrotal sac and closing the abdominal wall. The daily sperm output was then measured for 13 weeks. The data were subjected to an analysis of variance using a split plot p.q. design (Kirk, 1968). After the last sperm count, the bladder and the ductus deferens were removed at autopsy and prepared for histological examination (Plate 1).

\section{RESULTS}

In the urine of intact rats, a mean number ( \pm S.D.) of $128,000 \pm 162,000$ spermatozoa were eliminated daily. During the first few days after the anastomosis, blood was present in the urine. After 7 days, the leakage of blood had ceased in most animals and sperm counts were possible. The data recorded in this paper are derived from eight of the ten rats. In one rat, spermatozoa were not observed in the urine, and after sham operation in one Group-2 rat the

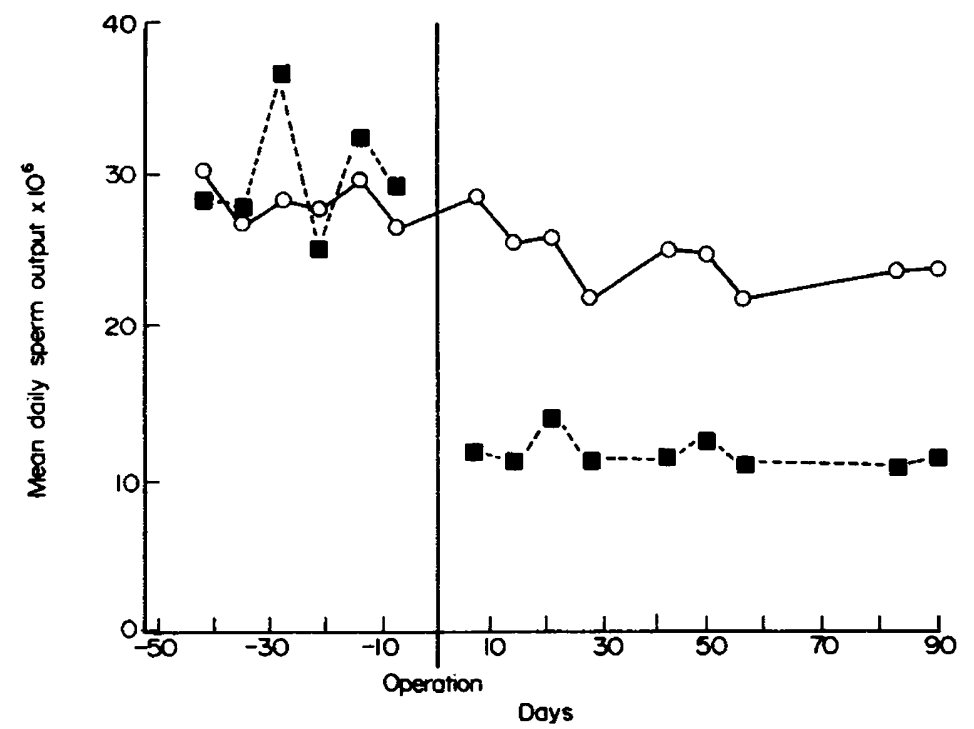

TEXT-FIG. 2. The effect of unilateral castration ( $\square$, Group 1, N =4) or sham operation ( 0 , Group $2, N=4$ ) on the mean daily sperm output in rats with an anastomosis between the ductus deferens and the bladder.

spermatozoa began to form clusters which made counting impossible. The sperm output of the rats in Groups 1 and 2 was identical during the 6 weeks before sham operation or hemicastration. During this period, the mean daily sperm output, $\times 10^{6} \pm$ S.D., in Group 2 was $28 \cdot 1 \pm 7 \cdot 0$, and in Group 1 was $29 \cdot 8 \pm 8 \cdot 0$. Following hemicastration, the sperm output rapidly diminished compared to that of the control animals. This decrease was statistically significant as indicated by a significant interaction effect in an overall analysis of variance $(F=3368$, d.f. $14 / 84, P<0 \cdot 01)$. During the postoperative period, the mean daily sperm output, $\times 10^{6} \pm$ S.D., in Group 2 was $24.4 \pm 6.5$ and in Group 1 was $11 \cdot 5 \pm 2 \cdot 1$. 


\section{DISCUSSION}

A constant number of spermatozoa was found in the urine of rats with an anastomosis between the ductus deferens and the bladder for over 4 months. Besides its simplicity, this method for measuring the sperm output has the advantage that all the spermatozoa that leave the ductus deferens appear in the urine and are counted in the daily output. With the ejaculation technique, losses of spermatozoa in the urine are usually not measured. In the rabbit during periods of sexual inactivity and periods of frequent ejaculation, appreciable numbers of spermatozoa can be found in the urine (Holtz \& Foote, 1972). This may account for the difference between the daily sperm output, i.e. the total number of ejaculated spermatozoa, and the daily sperm production by the testes expressed on a 'per day' basis, which has been found in the rabbit (Orgebin-Crist, 1968; Amann, 1970b) and in the bull (Amann \& Almquist, 1962). Another possibility is that sperm resorption in the epididymis and ductus deferens in these species is responsible for the discrepancy between production and output, but there is no direct evidence that an intensive sperm resorption occurs in the epididymis of the rabbit (Paufler \& Foote, 1969). Daily sperm output of boars is more than $80 \%$ of the daily sperm production (Swierstra, 1968), indicating that no intensive sperm resorption occurs in the epididymis of these animals. The number of spermatozoa found in the urine of rams during sexual inactivity indicates that little if any resorption occurs in this species (Lino, Braden \& Turnbull, 1967). No data are available about sperm production and output measured in individual rats. The capacity for sperm resorption by the rat epididymis must be limited since cysts containing spermatozoa are formed at the testicular cut end of the ductus deferens following unilateral vasectomy (Smith, 1962). Sackler, Weltman, Pandhi \& Schwartz (1973) suggested that the high frequency of cyst formation observed after vasectomy and vasoligation in the rat could be related to an inability of elements in the cauda epididymidis and ductus deferens competently to phagocytose the cellular débris arising from accumulation of fluid, live and dead spermatozoa and degenerated materials. This finding, together with the observation that regular spontaneous discharges of spermatozoa in the rat occur (Orbach, 1961), suggests that most of the spermatozoa produced by the testes are measured with our technique.

Our data from the rats in Group 1, showing that no compensatory increase

\section{EXPLANATION OF PLATE 1}

FIG. 1. A cross-section of the rat ductus deferens just within the bladder wall. The ductus is surrounded by the lumen of the bladder and at one point is connected to its wall. The arrow points to an accumulation of spermatozoa. The horizontal bar represents $1 \mathrm{~mm}$. Fig. 2. A cross-section of the place where the ductus deferens and the bladder have grown together. The arrow points to cells which form the beginning of the lumen of the bladder. The horizontal bar represents $0.1 \mathrm{~mm}$.

Fig. 3. A higher magnification of the accumulation of spermatozoa indicated by the arrow in Fig. 1. Note that the outside of the ductus deferens is covered by epithelial cells (arrow). The horizontal bar represents $0.1 \mathrm{~mm}$.

FIG. 4. A higher magnification from the cross-section shown in Fig. 1. The lumen of the ductus deferens contains spermatozoa. The horizontal bar represents $0.1 \mathrm{~mm}$. 


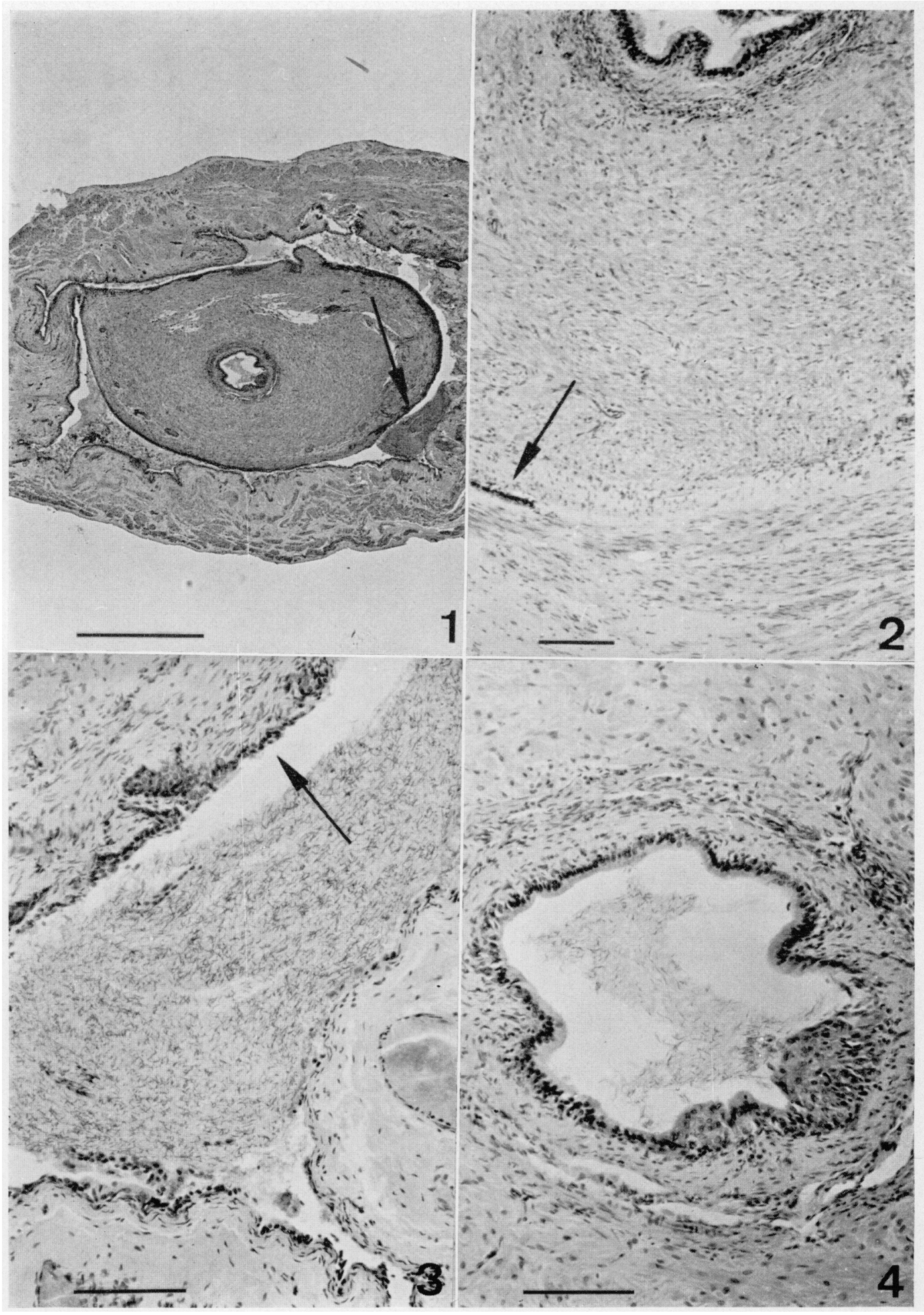


in the daily sperm output occurs after hemicastration, conflict with the results of Mauss \& Hackstedt (1972). Using an electroejaculation technique, these investigators found that the output of rats reached the preoperative level 1 month after unilateral castration. At present, there is no clear explanation for these discrepant findings. Setchell \& Waites (1972), however, demonstrated that unilateral castration had no effect on the weight of the remaining testis, on its fluid secretion or on the sperm concentration in this fluid.

It is evident that the present method is of value for long-term studies of sperm production in the rat and it may prove useful in similar studies performed with other types of laboratory animals.

\section{AGKNOWLEDGMENTS}

We thank Dr J. H. Aafjes, Dr M. J. Baum and Dr J. J. van der Werff ten Bosch for commenting on the manuscript. The technical assistance of $\mathrm{Mr}$ P. E. Schenck, Dr J. P. W. Vermeiden and Miss P. D. M. van der Vaart is gratefully acknowledged.

\section{REFERENGES}

Amann, R. P. (1970a) Sperm production rates. In The Testis, Vol. 1, p. 435. Eds. A. D. Johnson, W. R. Gomes and N. L. VanDemark. Academic Press, New York.

Amann, R. P. (1970b) The male rabbit. IV. Quantitative testicular histology and comparisons between daily sperm production as determined histologically and daily sperm output. Fert. Steril. 21, 662 .

Amann, R. P. \& AlmQuist, J. O. (1962) Reproductive capacity of dairy bulls. VIII. Direct and indirect measurement of testicular sperm production. F. Dairy Sci. 45, 774.

Birnbaum, D. \& Hall, T. (1961) An electroejaculation technique for rats. Anat. Rec. 140, 49.

Holtz, W. \& Foote, R. H. (1972) Sperm production, output and urinary loss in the rabbit. Proc. Soc. exp. Biol. Med. 141, 958.

KIRK, R. E. (1968) Split-plot design. In Experimental Design: Procedures for the Behavioral Sciences, p. 245. Brooks/Cole Publishing Co., Belmont, California.

Lawson, R. L., Krise, G. M. \& Sorensen, A. M. (1967) Electroejaculation and evaluation of semen from the albino rat. F. appl. Physiol. 22, 174.

Lino, B. F., Braden, A. W. H. \& Turnbull, K. E. (1967) Fate of unejaculated spermatozoa. Nature, Lond. 213, 594.

MAuss, J. \& HACKstedt, G. (1972) The effect of unilateral orchidectomy and unilateral cryptorchidism on sperm output in the rat. F. Reprod. Fert. 30, 289.

Mauss, J., Rausch-Stroomann, J. G., Hahn, E., Petry, R. \& Zambal, Z. (1970) Gewinnung, histologische Untersuchungen und Lösungsversuche des Ejakulatpropfes der Ratte. Andrologie, 2, 13.

Orbach, J. (1961) Spontaneous ejaculation in rat. Science, N.Y. 134, 1072.

ORGEBIN-Grist, M. C. (1968) Gonadal and epididymal sperm reserves in the rabbit: estimation of the daily sperm production. F. Reprod. Fert. 15, 15.

PaUfler, S. K. \& Foote, R. H. (1969) Sperm retention and resorption in sexually active rabbits with epididymal ligatures. Proc. Soc. exp. Biol. Med. 131, 1179.

RüMKE, P. \& TrTus, M. (1970) Spermagglutinin formation in male rats by subcutaneously injected syngeneic epididymal spermatozoa and by vasoligation or vasectomy. F. Reprod. Fert. 21, 69.

Sackler, A. M., Weltman, A. S., Pandhi, V. \& Schwartz, R. (1973) Gonadal effects of vasectomy and vasoligation. Science, N.Y. 179, 293.

Scotт, J. V. \& Dziuk, P. J. (1959) Evaluation of the electroejaculation technique and spermatozoa thus obtained from rats, mice and guinea pigs. Anat. Rec. 133, 655.

Serchell, B. P. \& Wartes, G. M. H. (1972) The effects of local heating of the testis on the flow and composition of rete testis fluid in the rat, with some observation on the effects of age and unilateral castration. 7. Reprod. Fert. 30, 225.

Sмrth, G. (1962) The effects of ligation of the vasa efferentia and vasectomy on testicular function in the adult rat. F. Endocr. 23, 385.

SWIERstra, E. E. (1968) A comparison of spermatozoa production and spermatozoa output of Yorkshire and Lacomb boars. F. Reprod. Fert. 17, 459. 